\title{
Implementasi Model Audit Pertanggungjawaban Sosial Berbasis Human-Centered Design pada Organisasi Sektor Publik
}

\author{
Priyo Suprobo ${ }^{*}$, Diana Suteja ${ }^{1}$, Soegeng Soetedjo ${ }^{2}$, Basuki $^{2}$ \\ ${ }^{1}$ Fakultas Teknik Universitas Widya Kartika, Jl. Sutorejo Prima Utara II/No. 1, Surabaya 60113 \\ ${ }_{2}^{2}$ Pascasarjana Ilmu Akuntansi, Fakultas Ekonomi, Universitas Airlangga Surabaya, \\ Jl. Airlangga No. 4-6, Surabaya 60286 \\ *Korespondensi penulis, email: suprobopriyo@gmail.com
}

\begin{abstract}
ABSTRAK
Penelitian sebelumnya telah menghasilkan suatu Model Audit Pertanggungjawaban Sosial berbasis Human-Centered Design, yang selanjutnya disebut HCD. Penelitian ini untuk memperoleh alternatif pendekatan yang lebih sederhana, efektif, dan cocok dalam menghubungkan masyarakat dengan organisasi sektor publik. Dengan demikian, penelitian kali ini bermaksud untuk menguji model tersebut dengan mengimplementasikannya pada organisasi sektor publik. Pendekatan penelitian adalah uji model audit dengan implementasi secara riil di lapangan. Hasil umpan balik atas uji implementasinya dilakukan dengan pendekatan secara kualitatif. Pengambilan sampel dilakukan secara purposive sampling dengan organisasi sektor publik yang diteliti adalah CV. Aidrat \& Toserba Pondok Pesantren Sunan Drajat Lamongan, RSAB Soerya Sidoarjo dan Universitas Widya Kartika Surabaya. Organisasi ini dipilih berdasarkan jenis organisasi sektor publik yang meliputi unit-unit usaha di bawah organisasi keagamaan, organisasi kesehatan, dan lembaga pendidikan. Di sisi lain juga ditentukan berdasarkan kesediaan bekerjasama dan area yang diwakili. Secara penilaian, hasil audit pertanggungjawaban sosial untuk kriteria aspek kelembagaan dan legal formal dalam preliminary survey, Universitas Widya Kartika dan RSAB Soerya termasuk berkategori baik. Sementara CV. Aidrat termasuk dalam kategori cukup. Dalam hal pengendalian internal, semua organisasi ini masuk dalam kategori cukup sedangkan dalam hal kinerja program untuk pertanggungjawaban sosial, CV. Aidrat dan RSAB Soerya memberikan nilai kinerja yang baik.
\end{abstract}

Kata kunci: Audit sosial, human-centered design, organisasi, sektor publik, model.

\begin{abstract}
Previous research has resulted the Model of Audit for Social Accountability based on Human-Centered Design, which is hereinafter referred to HCD. The present study aims to obtain the alternative audit approaches that are more simple, effective, and suitable in connecting people with public sector organizations. Thus, the present study intends to test the model by implementing it in public sector organizations. The research approach is to test the implementation of the audit model in real terms in the field. Feedback on implementation test is conducted by the qualitative approach. Sampling was done by purposive sampling and the public sector organizations studied were CV. Aidrat \& General Store of Pondok Pesantren Sunan Drajat Lamongan, Hospital RSAB Soerya Sidoarjo and the University of Widya Kartika Surabaya. These organizations were selected based on the type of public sector organizations covering the business units under religious organizations, health organizations, and educational institutions. On the other side, they are also determined by the willingness to cooperate and the area represented. In the assessment, the results of the audit to the criteria of social responsibility and a legal formal institutional aspect in the preliminary survey show that the University of Widya Kartika and RSAB Soerya have good performance, while CV. Aidrat has an acceptable performance. In terms of internal control, all of these organizations have an acceptable performance, while in terms of social responsibility programs, CV. Aidrat and RSAB Soerya have a good performance.
\end{abstract}

Keywords: Social audit, human-centered design, organization, public sector, model. 


\section{PENDAHULUAN}

Bentuk keluaran pertanggungjawaban sosial pada suatu organisasi hadir sebagai hasil dari kegiatan audit, dan secara garis besar dilakukan dengan dua cara, yakni audit kinerja program dengan mendasarkan pada indikator pencapaian dan audit akuntansi pertanggungjawaban sosial. Kedua audit pertanggungjawaban sosial ini bukan berarti selama ini tidak ada kendala. Beberapa kendala yang dapat ditemui diantaranya adalah 1) dibutuhkan waktu, usaha, dan biaya yang tidak sedikit; dan terutama 2) belum ada standar baku yang mengatur bagaimana seharusnya pertanggungjawaban sosial diungkapkan dalam suatu laporan (Damayanti 2010).

Menyikapi atas kajian Damayanti (2010) ini, maka dalam penelitian selanjutnya telah dikembangkan suatu Model Audit Pertanggungjawaban Sosial berbasis Human-Centered Design, yang selanjutnya disebut HCD (Suprobo et al. 2013). Human-Centered Design atau HCD adalah sebuah pengetahuan yang menggunakan sensibilitas desainer. Berpikir desain itu sebuah upaya mengajak kita semua untuk berpikir layaknya seorang desainer. Kegiatan berpikir desain adalah menerjemahkan observasi menjadi inspirasi dan inspirasi menjadi kreasi produk, jasa, proses dan bahkan model atau strategi demi kualitas kehidupan yang lebih baik. Semua itu adalah sebuah metodologi yang menginspirasi individu untuk memiliki alam inovatif dengan semangat desain yang berbasis manusia (Brown 2008). Dalam beberapa tahun terakhir, design thinking atau human centered design mulai lebih populer dan meluas penerapannya dibandingkan pada ranah asalnya untuk mendesain suatu produk atau layanan. Ada beberapa perluasan penerapan diantaranya adalah desain organisasi, rencana strategis, praktek-praktek manajemen, penciptaan bisnis baru, praktek-praktek pembelajaran dan bahkan inovasi sosial untuk pengembangan komunitas (Brown \& Wyatt 2010).

Adapun langkah-langkah Model Audit Pertanggungjawaban Sosial berbasis HCD yang perlu ditempuh adalah sebagai berikut:

1) Preliminary Survey atas Prosedur yang berlaku pada Organisasi

2) Menetapkan Standar Prosedur Audit yang disepakati dan Proses Auditnya

3) Melakukan Audit Pengendalian Internal atas semua Fungsi Organisasi

4) Pengembangan Hasil Audit \& Temuan

Model audit pertanggungjawaban sosial ini merupakan bagian dari hasil penelitian untuk memperoleh alternatif pendekatan audit pertanggungjawaban sosial yang lebih sederhana, efektif, dan bersesuaian dengan perannya untuk meng- hubungkan masyarakat dengan organisasi sektor publik (Suprobo et al. 2013).

Dengan demikian penelitian ini bermaksud untuk menindaklanjuti hasil penelitian tersebut, sehingga diperlukan suatu proses uji implementasi atas model ini hingga dapat dirumuskan suatu Pedoman Penerapan Model Audit Pertanggungjawaban Sosial yang dapat cocok bagi organisasi atau suatu entitas. Dengan mengikuti langkah dan proses yang ditawarkan dalam model ini, maka uji implementasi ini dijalankan pada beberapa organisasi usaha, diantaranya di bidang jasa dan retail. Hal ini masih bersesuaian dengan metode yang pernah dilakukan pada beberapa entitas dagang dan jasa seperti Beechwood, Body Shop, Traidcraft, LHTD, Cooperative Bank, dan APSO (Zhang et al. 2003). Diharapkan melalui implementasi ini akan didapatkan umpan balik perbaikan atas model ini.

Dilatarbelakangi atas hal ini, maka penelitian empiris ini bermaksud untuk dapat memberikan dampak atau manfaat penelitian secara keilmuan maupun kontribusinya dalam pembangunan. Penelitian ini akan memberikan kontribusi dalam bidang ilmu audit manajemen dan pertanggungjawaban sosial (Social Responsibility) serta ditemukannya pendekatan yang baru di bidang problem solving yang berorientasi pada kinerja masyarakat. Dalam hal pembangunan nasional, penelitian empiris ini memberikan wacana dan pedoman bagi praktek-praktek kegiatan audit pertanggungjawaban sosial di Indonesia.

\section{Model Audit Pertanggungjawaban Sosial berbasis Human-Centered Design (HCD)}

Standar Auditing adalah sepuluh standar yang ditetapkan dan disahkan oleh Institut Akuntan Publik Indonesia (IAPI), yang terdiri dari standar umum, standar pekerjaan lapangan, dan standar pelaporan beserta interpretasinya. Standar auditing merupakan pedoman audit atas laporan keuangan historis. Standar auditing ini dirinci dalam bentuk Pernyataan Standar Auditing (Publik I.A.I.K.A. 2001). Di Amerika Serikat, standar auditing semacam ini disebut Generally Accepted Auditing Standards (GAAS) yang dikeluarkan oleh the American Institute of Certified Public Accountants (AICPA).

PSA berisi ketentuan-ketentuan dan pedoman utama yang harus diikuti oleh Akuntan Publik dalam melaksanakan penugasan audit. Kepatuhan terhadap PSA yang diterbitkan oleh IAPI ini bersifat wajib bagi seluruh anggota IAPI. Termasuk didalam PSA adalah Interpretasi Pernyataan Standar Auditng (IPSA), yang merupakan interpretasi resmi yang dikeluarkan oleh IAPI terhadap ketentuan-ketentuan yang diterbitkan oleh IAPI dalam PSA. Dengan demikian, IPSA 
memberikan jawaban atas pernyataan atau keraguan dalam penafsiran ketentuan-ketentuan yang dimuat dalam PSA sehingga merupakan perluasan lebih lanjut berbagai ketentuan dalam PSA. Tafsiran resmi ini bersifat mengikat bagi seluruh anggota IAPI, sehingga pelaksanaannya bersifat wajib. Setelah mempertimbangkan lingkup isi/Aspek Pertanggungjawaban Sosial dan faktor profesionalisme Auditor, maka hasil pengembangan menjadi Model Audit Pertanggungjawaban Sosial dengan metode HCD adalah seperti pada Gambar 1.

Tujuan dari preliminary survey adalah untuk mendapatkan informasi umum dan latar belakang dalam waktu yang relatif singkat, mengenai semua aspek dari organisasi, kegiatan, program atau sistem yang dipertimbangkan untuk diperiksa. Hal ini agar dapat diperoleh pengetahuan atau gambaran yang memadai mengenai obyek pemeriksaan. Informasi umum dan latar belakang yang diperlukan misalnya dapat dipetakan seperti pada Tabel 1

Selanjutnya dari hasil preliminary survey, kegiatan audit dapat menetapkan standar prosedur yang disepakati terkait dengan entitas yang akan diaudit. Setelah disepakati antara tim auditor dan entitas, maka kegiatan audit dapat dilakukan melalui kuisioner pengendalian intern dan kuisioner organisasi fungsional, yang selanjutnya disimpulkan dan didokumentasikan dalam suatu daftar temuan audit. Kesimpulan bisa menyatakan bahwa tidak ada masalah atau kelemahan yang ditemukan tetapi dapat pula menyimpulkan hal-hal yang memerlukan perhatian manajemen.

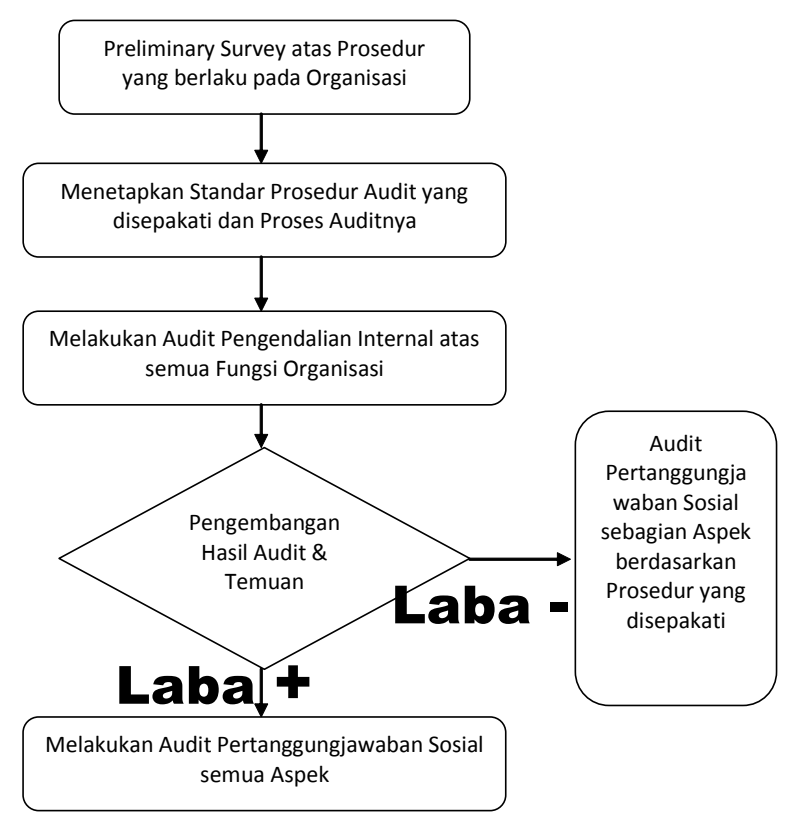

Sumber: Suprobo et al (2013)

Gambar 1. Model Audit Pertanggungjawaban Sosial berbasis HCD
Tabel 1. Pemetaan Informasi dalam Preliminary Survey

\begin{tabular}{|c|c|}
\hline $\begin{array}{l}\text { Lingkup } \\
\text { Informasi }\end{array}$ & Jenis Informasi Dibutuhkan \\
\hline Organisasi & $\begin{array}{l}\text { - Lokasi } \\
\text { - Manajemen } \\
\text { - Sejarahnya } \\
\text { - Jumlah Pegawai } \\
\text { - Kebijakan Manajemen } \\
\text { - Kewajiban/Aspek Hukum } \\
\text { - Akta pendirian \& Perubahan serta } \\
\text { pengesahan } \\
\text { - Kewajiban-kewajibannya }\end{array}$ \\
\hline Suatu Aktivi & $\begin{array}{l}\text { - Jenis Aktivitas } \\
\text { - Lokasi } \\
\text { - Orang yang bertanggung jawab pada } \\
\text { aktivitas tersebut } \\
\text { - Kebijakan yang menyangkut Aktivitas } \\
\text { - Prosedur khusus untuk penyelesaian } \\
\text { aktivitas }\end{array}$ \\
\hline Suatu Program & $\begin{array}{l}\text { - Tujuan Program } \\
\text { - Hubungan antar organisasi/unit yang } \\
\text { dibentuk atau digunakan untuk } \\
\text { mencapai tujuan tertentu } \\
\text { - Kebijakan dan prosedur untuk } \\
\text { menyelesaikan program tersebut } \\
\text { - Peraturan-peraturan Administrative } \\
\text { yang berkaitan dengan program } \\
\text { tersebut }\end{array}$ \\
\hline
\end{tabular}

Tabel 2. Komponen Temuan Audit Pertanggungjawaban Sosial

\begin{tabular}{|c|c|}
\hline Komponen Temuan & Isi Keterangan \\
\hline - Kriteria & $\begin{array}{l}\text { :Ukuran atau standar yang } \\
\text { harus diikuti atau kondisi yang } \\
\text { seharusnya ada }\end{array}$ \\
\hline - Pernyataan Kondisi & $\begin{array}{l}\text { :Bagaimana kenyataan atau } \\
\text { kondisi yang terjadi di } \\
\text { perusahaan }\end{array}$ \\
\hline - Akibat & $\begin{array}{l}\text { :Bagaimana akibat dari } \\
\text { kenyataan yang terjadi di } \\
\text { perusahaan jika akibat negative } \\
\text { berupa penyimpangan, akibat } \\
\text { positif berupa hasil yang baik } \\
\text { dari standar yang sudah } \\
\text { ditentukan. }\end{array}$ \\
\hline - Sebab & $\begin{array}{l}\text { :Apa penyebab terjadinya kondisi } \\
\text { tersebut di perusahaan dan } \\
\text { bagaimana terjadinya. }\end{array}$ \\
\hline
\end{tabular}

Sifat temuan dapat kemudian menunjukkan kondisi pada keuntungan secara finansial yang berimplikasi negatif maupun positif. Temuan menunjukkan keuntungan yang positif dapat menyebutkan bahwa tidak ada masalah yang ditemukan, dapat pula menyebutkan kebaikan pengendalian intern yang terdapat disalah satu bagian yang perlu diterapkan di bagian lain. Temuan menunjukkan berdampak pada keuntungan yang negatif memberitahukan kepada 
manajemen masalah-masalah yang ditemukan dan tindakan perbaikan dari manajemen untuk mencegah kerugian-kerugian yang timbul akibat masalah tersebut. Temuan yang baik disusun dengan memperhatikan poin-poin seperti pada Tabel 2

\section{Organisasi Sektor Publik}

Organisasi sektor publik mempunyai karakteristik tersendiri dibandingkan dengan organisasi komersial. Perbedaan yang paling mencolok adalah dalam kepemilikan (ownership). Dalam hal kepemilikian pada perusahaan komersial ditandai dengan adanya kepemilikan saham atau jumlah saham tersetor, yang selanjutnya disebut modal saham (capital stock). Pada organisasi sektor publik, kepemilikan tidak ditandai dengan kepemilikan saham melainkan dapat dilihat dari dana yang dihimpun berasal dari publik. Organisasi sektor publik menjadi berbeda dan unik karena ciri-ciri sebagai berikut:

1. Dijalankan tidak untuk mencari keuntungan finansial

2. Dimiliki secara kolektif oleh publik

3. Kepemilikan atas sumberdaya tidak digambarkan dalam bentuk saham yang dapat diperjualbelikan

4. Keputusan-keputusan yang terkait kebijakan maupun operasi didasarkan pada konsensus, sedangkan kalau organisasi pemerintah melalui suatu badan legislatif.

Organisasi sektor publik ini dapat dikelompokan menjadi enam, yakni lembaga pemerintah, organisasi keagamaan, organisasi sosial, yayasan, lembaga pendidikan, dan organisasi kesehatan (Karyana 2005). Sedangkan menurut Bakesbang, organisasi sektor publik di luar pemerintah adalah organisasi kemasyarakatan yang di dalamnya meliputi organisasi keagamaan, kepemudaan, wanita, profesi, fungsionaris, penghayat kepercayaan dan lembaga swadaya masyarakat.

Pentingnya pertanggungjawaban sosial dilakukan pada organisasi publik dibuktikan dengan penghargaan United Nation's Public Service Awards sejak tahun 2003. Penghargaan dari PBB ini dimaksudkan untuk dapat meningkatkan peran, profesionalisme dan visibility dari pelayanan publik dengan tiga kategori dasar, yakni transparansi dan akuntabilitas, perbaikan layanan dan aplikasi ICT (Information and Communication Technology). Dengan demikian, secara tidak langsung PBB melalui United Nation's Department of Economic and Social Affairs (UNDESA) mengakui diperlukannya cara-cara inovatif dari suatu organisasi publik dalam prosesnya untuk lebih akuntabel. Dinamika eksternal dan perubahan kesadaran masyarakat yang lebih baik akan haknya inilah yang mendorong sudah saatnya organisasi publik berinovasi dalam proses pertanggungjawaban sosialnya (Suwarno 2009).

Pertumbuhan organisasi kemasyarakatan yang tinggi dengan rata-rata $12 \%$ per tahunnya di Jawa Timur menunjukkan juga indikator pergeseran paradigma pembangunan dari ekonomi sebagai sentral (capital centered development) kepada manusia sebagai pusat utama pembangunan (people centered development). Upaya penguatan dan pemberdayaan masyarakat sudah menjadi kebutuhan saat ini, diantaranya melalui sarana organisasi sektor publik. Selain itu, pemberdayaan sektor publik ini juga perlu didukung dalam hal penguatan struktural kebijakan dan pemerataan kesempatan (Munandar 2008).

\section{METODE PENELITIAN}

\section{Desain dan Data Penelitian}

Pendekatan penelitian ini adalah uji model dengan implementasi secara riil di lapangan atas model audit pertanggungjawaban sosial yang dihasilkan oleh Suprobo et al. (2013). Hasil umpan balik atas uji implementasi model ini dilakukan dengan pendekatan secara kualitatif. Jenis data yang diharapkan adalah hasil uji implementasi model audit dan umpan balik melalui hasil wawancara terfokus, catatan lapangan, dan dokumentasi. Sumber data sendiri diperoleh melalui skoring hasil audit yang terukur dan beberapa informasi umpan balik dari para informan untuk menilai tingkat efektifitas penerapan Model.

\section{Lokasi dan Waktu}

Pengambilan sampel dilakukan secara purposive sampling dengan organisasi atau entitas yang diteliti adalah berfokus pada bidang jasa dan retail. Entitas yang diteliti dalam uji implementasi ini diantaranya adalah CV. Aidrat \& Toko Serba Ada Pondok Pesantren Sunan Drajat Lamongan, RSAB Soerya Sidoarjo dan Universitas Widya Kartika Surabaya. Organisasi dipilih berdasarkan pertimbangan jenis organisasi sektor publik yang meliputi unit-unit usaha di bawah organisasi keagamaan, organisasi kesehatan, dan lembaga pendidikan. Di sisi lain juga ditentukan berdasarkan kesediaan sebagai mitra dan bekerjasama dalam uji implementasi model, dan area yang diwakili. Dengan demikian, kegiatan penelitian difokuskan di Surabaya dan sekitarnya dengan lokasi utama diantaranya adalah di Surabaya, Sidoarjo dan Lamongan. 


\section{Teknik Pengumpulan Data}

Pengumpulan datanya sendiri dilakukan dengan beberapa cara, yakni melalui observasi dengan dokumentasi dan kegiatan kuisioner ataupun wawancara mendalam dan focus group discussion. Semua hal ini untuk mendukung hasil penilaian uji model audit secara kuantitatif ataupun untuk umpan balik dengan pendekatan kualitatif.

\section{Teknik Pengolahan dan Analisis Data}

Dalam analisis kualitatif, karena sifatnya yang terbuka (open ended), maka cenderung untuk adaptif melakukan perubahan, perbaikan, dan penyempurnaan berdasarkan data umpan balik yang baru. Adapun langkah-langkah perbaikan yang dilakukan dijabarkan dalam tahap evaluasi dan evolusi dengan metode human centered design, yang menjadi dasar pembentukan model audit pertanggungjawaban sosial ini.

Keabsahan data penelitian kualitatif dilakukan dengan melalui kredibilitas, dependabilitas, konfirmabilitas, dan transferabilitas. Teknik triangulasi dapat digunakan untuk

\section{ANALISIS DAN PEMBAHASAN}

\section{Hasil Audit Pertanggungjawaban Sosial}

Implementasi Model Audit Pertanggungjawaban Sosial berbasis HCD atas organisasi sektor publik dapat dilaporkan dengan mendasarkan pada komponen temuan, yang meliputi kriteria, pernyataan kondisi, akibat dari kondisi tersebut dan sebab mengapa kondisi tersebut terjadi. Khusus baris kriteria ditetapkan standar baku yang harus dipenuhi oleh suatu organisasi publik, diantaranya adalah sebagai berikut:

a) memiliki dokumentasi kelembagaan secara resmi dengan pembagian yang jelas antara hak dan kewajiban pada struktur organisasinya

b) memiliki kinerja yang baik dalam pengendalian internal di organisasi fungsionalnya dari meliputi aspek pemasaran, akuntansi, keuangan dan personalia

c) memiliki kinerja program yang baik dalam pertanggungjawaban sosial organisasinya baik secara internal maupun bagi masyarakat, dari meliputi aspek tata nilai organisasi, hubungan masyarakat, lingkungan, pengendalian keuangan dan hubungan dengan karyawan

Sementara dalam kolom organisasi sektor publik yang diteliti akan terbagi atas organisasi keagamaan melalui unit-unit usahanya, organisasi kesehatan dan lembaga pendidikan. Sebagaimana telah disampaikan di sub bagian Metode Penelitian bahwa untuk organisasi keagamaan diwakili oleh Pondok Pesantren Sunan Drajat melalui unit usaha CV. Airdrat \& Toserba di Lamongan. Sementara untuk lembaga kesehatan diwakili oleh RSAB Soerya di Sidoarjo dan terakhir untuk lembaga pendidikan diwakili oleh Universitas Widya Kartika di Surabaya.

Selanjutnya dari hasil pemetaan komponen temuan ini dapat ditarik suatu umpan balik untuk perbaikan yang dianggap perlu atas implementasi Model Audit Pertanggungjawaban Sosial berbasis HCD. Pendekatan perbaikan dilakukan dengan metode Human-Centered Design, yang salah satunya dengan spesifik melakukan proses refinement atau perbaikan dengan cara brainstorming dan ideation kembali atas hasil yang diperoleh maupun informasi umpan balik dari organisasi sektor publik yang diteliti.

Adapun secara rekapitulasi dapat dilaporkan Kondisi Hasil Audit Pertanggungjawaban Sosial berbasis HCD atas organisasi sektor publik tersebut sebagaimana di Tabel 3.

Secara penilaian, hasil audit pertanggungjawaban sosial untuk kriteria aspek kelembagaan dan legal formal dalam preliminary survey, Universitas Widya Kartika dan RSAB Soerya termasuk berkategori baik. Sementara CV. Aidrat termasuk dalam kategori cukup.

Dalam hal pengendalian internal, semua organisasi ini masuk dalam kategori cukup sedangkan dalam hal kinerja program untuk pertanggungjawaban sosial, CV. Aidrat dan RSAB Soerya memberikan nilai kinerja yang baik.

\section{Fokus Kegiatan Pertanggungjawaban Sosial Organisasi Sektor Publik}

Dari sekian kegiatan pertanggungjawaban sosial yang dilaksanakan oleh semua organisasi tersebut di atas, maka diantaranya dapat dikategorikan dalam beberapa hal terkait aspek yang diaudit. Diantaranya dapat disampaikan dalam bentuk bagan seperti pada Gambar 2 .

\section{Basis Organisasi Sektor Publik}

Organisasi sektor publik yang dibangun sebagaimana menurut Karyana (2005) ini dijalankan tidak untuk mencari keuntungan finansial. Sementara secara kepemilikan walaupun didirikan oleh anggota masyarakat yang peduli tetapi secara kelembagaan mengambil bentuk yayasan, sehingga mencanangkan kelembagaan formalnya tidak diperuntukkan mencari keuntungan secara komersiil. Dengan demikian, lembaga formal yayasan ini mendapatkan dana dari masyarakat untuk dikembalikan kepada masyarakat dalam bentuk meningkatkan kesejahteraan masyarakat sebagai segmen organisasinya, termasuk juga untuk pertanggungjawaban sosialnya. 
Tabel 3. Kondisi Hasil Audit Pertanggungjawaban Sosial berbasis HCD

\begin{tabular}{|c|c|c|c|}
\hline Komponen Temuan & $\begin{array}{c}\text { Organisasi Keagamaan } \\
\text { CV. Aidrat Ponpes Sunan Drajat } \\
\text { Lamongan }\end{array}$ & $\begin{array}{c}\text { Lembaga Kesehatan } \\
\text { RSAB Soerya } \\
\text { Sidoarjo } \\
\end{array}$ & $\begin{array}{c}\text { Lembaga Pendidikan } \\
\text { Universitas Widya Kartika Surabaya }\end{array}$ \\
\hline Pernyataan Kondisi & 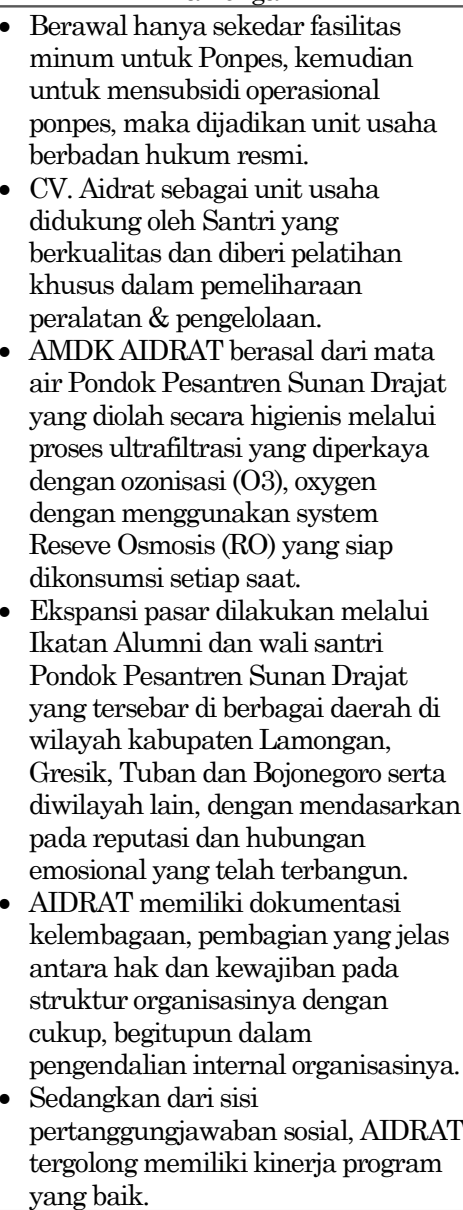 & $\begin{array}{l}\text { - Berawal dari klinik yang } \\
\text { sederhana kemudian bertumbuh } \\
\text { menjadi skala Rumah Sakit } \\
\text { Anak \& Bunda. } \\
\text { - RSAB Soerya dibangun } \\
\text { berlandaskan bisnis keluarga } \\
\text { dengan dasar kekeluargaan dan } \\
\text { hubungan emosional yang dekat } \\
\text { diantara pendiri/stakeholder } \\
\text { - Standarisasi aturan Rumah } \\
\text { Sakit bersalin dipenuhi dengan } \\
\text { baik sebagai ketentuan utama } \\
\text { - Aspek keuangan yang tidak } \\
\text { didasarkan pada unit biaya } \\
\text { melainkan volume menjadikan } \\
\text { RSAB Soerya selama ini dapat } \\
\text { mempertahankan daur hidup } \\
\text { operasionalnya. } \\
\text { - Aspek pasar dilakukan dengan } \\
\text { memberikan klasifikasi segmen } \\
\text { mengingat potensi wilayah yang } \\
\text { lebih banyak di pangsa pasar } \\
\text { menengah ke bawah. } \\
\text { - RSAB Soerya memiliki } \\
\text { dokumentasi kelembagaan, } \\
\text { pembagian yang jelas antara } \\
\text { hak dan kewajiban pada } \\
\text { struktur organisasinya dengan } \\
\text { baik, sementara dalam } \\
\text { pengendalian internal } \\
\text { organisasinya tergolong cukup } \\
\text { baik. } \\
\text { memiliki kinerja program yang } \\
\text { baik. }\end{array}$ & $\begin{array}{l}\text { - Universitas Widya Kartikaberdiri } \\
\text { bermula dari Universitas yang } \\
\text { hanya menampung golongan } \\
\text { tertentu tetapi kemudian } \\
\text { berkembang menjadi universitas } \\
\text { yang multikultural untuk semua } \\
\text { elemen bangsa. } \\
\text { - Berdiri di bawah Yayasan } \\
\text { Pendidikan \& Pengajaran } \\
\text { Indonesia (YPPI) yang berfokus } \\
\text { pada pendidikan dari TK sd } \\
\text { SMA/SMK, menjadikan } \\
\text { Universitas Widya Kartika } \\
\text { berbenah untuk mengikuti Sistim } \\
\text { Pendidikan Nasional dan } \\
\text { standarisasi pendidikan tinggi yang } \\
\text { berlaku. } \\
\text { - Aspek pemasaran, akuntansi, } \\
\text { keuangan dan personalia diatur } \\
\text { secara terpusat di bawah bidang } \\
\text { non akademik. Sedangkan untuk } \\
\text { kebijakan akademik diatur dengan } \\
\text { sebagian bersifat desentralisasi di } \\
\text { tingkat fakultas maupun program } \\
\text { studi. } \\
\text { - Universitas Widya Kartika } \\
\text { memiliki dokumentasi } \\
\text { kelembagaan, pembagian yang } \\
\text { jelas antara hak dan kewajiban } \\
\text { pada struktur organisasinya } \\
\text { begitupun dalam pengendalian } \\
\text { internal organisasinya. } \\
\text { pertanggungjawaban sosial, } \\
\text { Universitas Widya Kartika masih } \\
\text { tergolong memiliki kinerja program } \\
\text { yang baik. }\end{array}$ \\
\hline Akibat & $\begin{array}{l}\text { Akibat dari kondisi ini menunjukkan } \\
\text { indikator yang baik, diantaranya } \\
\text { adalah: } \\
\text { - AIDRAT sampai kewalahan } \\
\text { memenuhi permintaan pasar di } \\
\text { beberapa daerah } \\
\text { - Omset AIDRAT terus beranjak naik } \\
\text { pada setiap tahunnya } \\
\text { - Dimampukannya AIDRAT untuk } \\
\text { mengadakan penambahan } \\
\text { peralatan/mesin baru }\end{array}$ & $\begin{array}{l}\text { Akibat dari kondisi ini } \\
\text { menunjukkan indikator yang baik, } \\
\text { diantaranya adalah: } \\
\text { - RSAB Soerya menunjukkan } \\
\text { perkembangan secara bertahap } \\
\text { - Dimampukannya RSAB Soerya } \\
\text { untuk merencanakan } \\
\text { pembukaan klinik baru untuk } \\
\text { segmen eksklusif di depan RSAB } \\
\text { Soerya }\end{array}$ & $\begin{array}{l}\text { Akibat dari kondisi ini menunjukkan } \\
\text { indikator yang cukup baik, } \\
\text { diantaranya adalah: } \\
\text { - Universitas Widya Kartika } \\
\text { menunjukkan perkembangan } \\
\text { menuju ke arah perbaikan secara } \\
\text { bertahap } \\
\text { - Dimampukannya Universitas } \\
\text { Widya Kartika bertahan dalam } \\
\text { operasionalnya dengan dipercaya } \\
\text { menerima Hibah PHP PTS dua } \\
\text { kali. }\end{array}$ \\
\hline Sebab & $\begin{array}{l}\text { Penyebab utama adalah adanya ikatan } \\
\text { emosional yang terbangun baik antara } \\
\text { AIDRAT dengan konsumen \& } \\
\text { sekaligus distributor yang adalah juga } \\
\text { para alumni Ponpes Sunan Drajat. } \\
\text { Emosi yang terbangun ini disebabkan } \\
\text { juga salah satunya adalah karena } \\
\text { AIDRAT menyediakan diri sebagai } \\
\text { sarana belajar para santri, sebagai } \\
\text { tempat untuk berusaha bersama dan } \\
\text { juga sebagai bapak asuh dalam } \\
\text { penyediaan beasiswa bagi santri yang } \\
\text { berprestasi. }\end{array}$ & $\begin{array}{l}\text { Penyebab utama adalah adanya } \\
\text { upaya dari RSAB Soerya untuk } \\
\text { mengadakan ikatan toleransi } \\
\text { dengan masyarakat sekitar } \\
\text { maupun dengan para karyawan di } \\
\text { lingkup internalnya. } \\
\text { Beberapa bentuk toleransi ke } \\
\text { masyarakat sekitar diantaranya } \\
\text { melalui Bakti Sosial ataupun } \\
\text { penyuluhan kesehatan keliling } \\
\text { serta kartu periksa gratis. } \\
\text { Sedangkan di sisi internal banyak } \\
\text { dilakukan melalui selain } \\
\text { menerimakan hak-hak karyawan } \\
\text { sesuai aturan, juga } \\
\text { ditambahkannya insentif lainnya. }\end{array}$ & $\begin{array}{l}\text { Penyebab utama adalah adanya } \\
\text { upaya dari Universitas Widya Kartika } \\
\text { untuk konsolidasi ke dalam dengan } \\
\text { berbenah diri melalui pembenahan } \\
\text { kualitas SDM di lingkungan internal } \\
\text { dan budaya mutu yang baik serta } \\
\text { membangun kepercayaan di antara } \\
\text { komponen organisasi. } \\
\text { Sedangkan aktifitas positif eksternal } \\
\text { lainnya adalah mulainya Universitas } \\
\text { Widya Kartika untuk membuka diri } \\
\text { ke luar, menyampaikan diri ke } \\
\text { masyarakat melalui beberapa } \\
\text { kegiatan terbuka dan bermanfaat bagi } \\
\text { masyarakat, seperti Bakti Sosial, } \\
\text { Donor Darah, General Check Up } \\
\text { gratis dan pelatihan-pelatihan } \\
\text { ketrampilan lainnya. }\end{array}$ \\
\hline
\end{tabular}




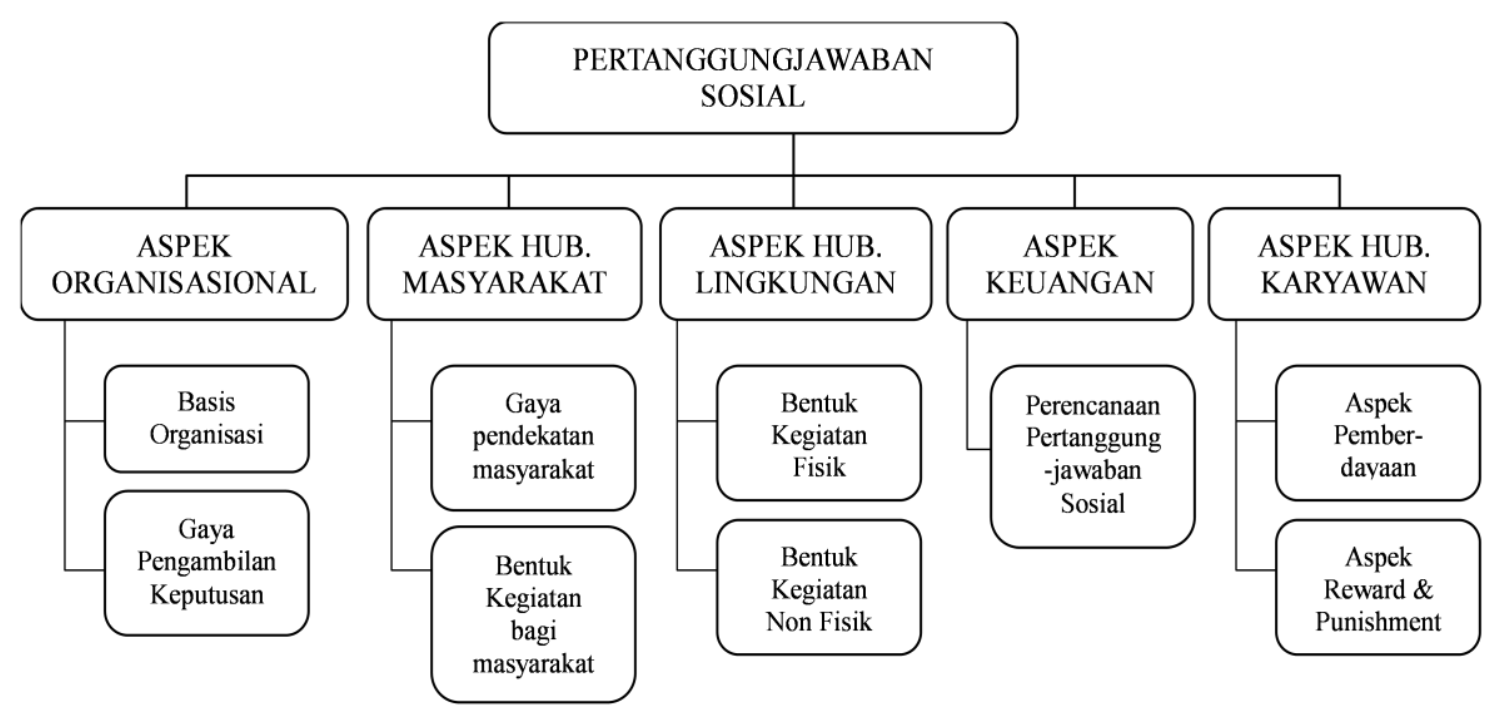

Gambar 2. Fokus Pertanggungjawaban Sosial Organisasi Sektor Publik

Pondok Pesantren Sunan Drajat sebagai lembaga pendidikan di bawah Departemen Agama yang mengambil bentuk organisasi yayasan keagamaan memantapkan dirinya untuk bertahan dan mandiri dalam menjalankan pendidikan bagi masyarakat dengan membentuk unit usaha seperti CV. AIDRAT dan Toserba. Hal ini meskipun bersifat kepemilikan pribadi dengan maksud mendapatkan keuntungan tetapi kesemuanya itu untuk mendukung operasional dan mensubsidi pengeluaran yang ada di Pondok Pesantren Sunan Drajat.

Hal ini sedikit berbeda di organisasi RSAB Soerya dan Universitas Widya Kartika yang berlindung dalam kelembagaan yayasan yang di dalamnya para pendirinya justeru menyisihkan sebagian hartanya untuk mensejahterakan masyarakat sesuai bidang yang dipilih, yakni untuk kesehatan dan pendidikan. Harta yang disisihkan ini selanjutnya dikelola dalam upaya untuk mendapatkan dana dari masyarakat melalui pemberian layanan kesehatan oleh RSAB Soerya dan layanan pendidikan oleh Universitas Widya Kartika. Dengan demikian kepemilikan atas sumber daya yang ada tidak dirupakan dalam bentuk sahan yang dapat diperjualbelikan, melainkan diatur melalui kebijakan yang didasarkan pada konsensus dengan melibatkan para organ yayasan, diantaranya adalah Pembina, Pengurus, Pengawas dan Lembaga Pelaksananya.

\section{Gaya Pengambilan Keputusan}

Gaya pengambilan keputusan dalam uji implementasi Model Audit Pertanggungjawaban Sosial ini dapat dikategorikan menjadi 2 (dua), yakni Gaya Analitik dan Gaya Konseptual (Setioko 2010).

Gaya analitik mempunyai toleransi yang tinggi untuk ambiguitas dan tugas serta berorientasi teknis. Gemar menganalisis situasi, mengevaluasi lebih banyak informasi dan cenderung memerlukan waktu lama untuk mengambil keputusan dalam merespons situasi baru atau tidak menentu adalah cirikhas gaya ini. Organisasi yang bergaya seperti ini juga cenderung mempunyai gaya kepemimpinan otokratis. Universitas Widya Kartika sebagai lembaga pendidikan yang didirikan oleh Yayasan YPPI yang bertumbuh besar dan sudah berpengalaman dalam pendirian Sekolah TK sampai dengan SMA/SMK menjadikannya sebagai lembaga yang profesional dengan pendekatan yang bersifat analitik dalam mengambil keputusan dan cenderung melibatkan para organ yayasannya dan bahkan stakeholder untuk kepentingan yang melibatkan semua pihak.

Hal ini sedikit berbeda pada Yayasan di Pondok Pesantren Sunan Drajat melalui unit usahanya dan juga Yayasan Soerya di RSAB Soerya yang cenderung bergaya Konseptual. Organisasi seperti ini mempunyai toleransi tinggi untuk ambiguitas dan cenderung peduli pada lingkungan sosial. Organisasi ini suka mempertimbangkan banyak pilihan dan kemungkinan yang terjadi di masa mendatang serta membahasnya dengan orang sebanyak mungkin di lingkungan terdekat untuk mendapat sejumlah informasi. Atas semua informasi yang ada dan kemudian mengandalkan intuisi, maka pemeran utama organisasi akan mengambil keputusan. Tidak jarang, organisasi seperti ini akan berani 
mengambil risiko dan cenderung bagus dalam menemukan solusi yang kreatif atas masalah.

\section{Gaya Pendekatan Organisasi ke Masyarakat}

Gaya pendekatan organisasi sektor publik ke masyarakat dalam kaitannya di aspek hubungan masyarakat seharusnya dilakukan pola dua arah. Kenyataan di lapangan, pola dua arah ini terjadi di Pondok Pesantren Sunan Drajat Lamongan sementara untuk pola inisiatif satu arah oleh organisasi terjadi di RSAB Soerya Sidoarjo dan Universitas Widya Kartika Surabaya. Hal ini sangat dimungkinkan cara pandang organisasi dalam melihat hubungannya dengan masyarakat.

Pola dua arah akan mungkin terwujud apabila organisasi sektor publik ini memandang pendekatan hubungan ke masyarakat adalah sebagai pendekatan mitra, sementara pola satu arah masih dimungkinkan karena adanya cara pandang organisasi sektor publik dalam memandang dirinya sebagai pemberi donasi dan aspek hubungan masyarakat sebagai bagian dari aksi komunikasi pencitraan yang positif (Irianta 2004; Imran 2012)

\section{Bentuk Kegiatan Organisasi bagi Masyarakat}

Organisasi sektor publik melakukan pendekatan hubungan ke masyarakat dengan berbagai bentuk kegiatan. Bentuk kegiatan pola dua arah yang dilakukan oleh Pondok Pesantren Sunan Drajat melalui unit usaha AIDRAT diantaranya adalah pemberian air bersih yang langsung bisa diminum tidak hanya oleh para warga pondok melainkan juga oleh para warga masyarakat sekitar. Sementara masyarakat sekitar melakukan pola inisiatif ke para pengasuh Pondok Pesantren untuk memberikan layanan ransum terjadwal bagi para santri ataupun para tamu pondok.

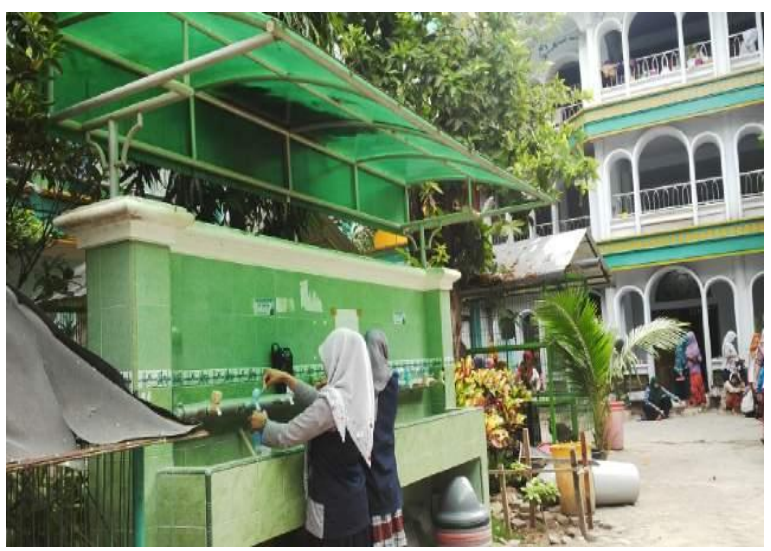

Gambar 3. Pemberian layanan air bersih langsung minum pada para santri \& warga

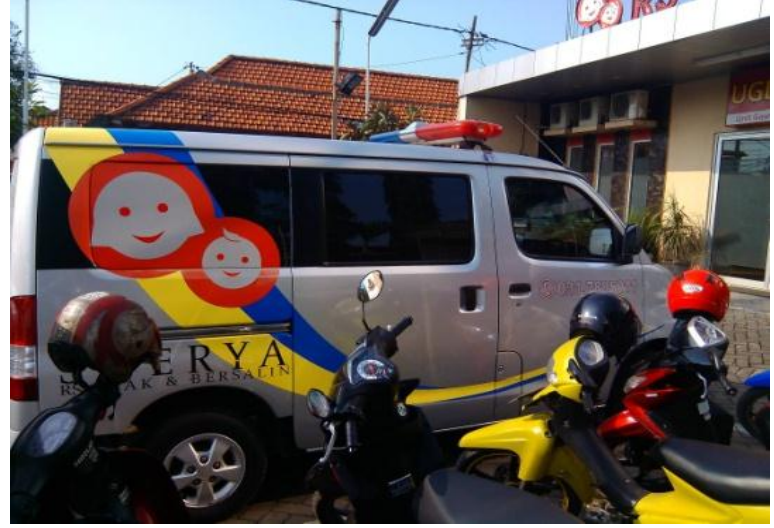

Gambar 4. Sarana Hospital Mobile oleh RSAB Soerya

Beberapa kegiatan lainnya berkaitan dengan hubungan masyarakat yang biasa dilakukan oleh RSAB Soerya diantaranya adalah Hospital Mobile atau Penyuluhan Kesehatan Gratis dengan disertakan bakti sosial pengobatan gratis. Kegiatan ini didukung juga dengan program kartu pengobatan gratis yang diberikan kepada warga sekitar. Hal ini dilaksanakan sebagai kegiatan berkala oleh RSAB Soerya sebagai upaya memperkenalkan diri dan sekaligus pencitraan di wilayah sekitar daerah distrik Taman, Sidoarjo. Hal bakti sosial ini juga menjadi menu berkala yang dilakukan oleh Universitas Widya Kartika diantaranya dengan kegiatan donor darah, pembagian sembako, pengobatan gratis maupun pemberian general check-up secara gratis.

Untuk kegiatan hubungan masyarakat yang tidak langsung berkaitan dengan warga masyarakat sekitar juga dilakukan oleh Universitas Widya Kartika maupun Pondok Pesantren Sunan Drajat, diantaranya adalah dengan pemberian beasiswa pendidikan maupun pelatihan gratis kepada masyarakat secara umum dalam berbagai bidang untuk peningkatan ketrampilan maupun keahlian.

\section{Bentuk Kegiatan Fisik Organisasi ke Ling- kungan}

Bentuk kegiatan fisik dapat berupa pembangunan infrastruktur untuk memenuhi standar pengelolaan lingkungan yang disyaratkan. Dalam hal ini pengelolaan yang dilakukan oleh RSAB Soerya dan Universitas Widya Kartika telah memenuhi standar.

Khusus untuk area kawasan Pondok Pesantren Sunan Drajat, pengelolaan sanitasi hunian para santri perlu mendapat perhatian serius, sementara untuk kawasan unit usaha AIDRAT terdapat perbedaan signifikan. Unit usaha ini telah terfasilitasi pengelolaan limbah yang baik 
dan ditunjang dengan tindakan konservasi melalui kegiatan pertanian dan perkebunan di sekitar sumber mata airnya.

\section{Bentuk Kegiatan Non Fisik Organisasi ke Lingkungan}

Untuk bentuk kegiatan non fisik bagi lingkungan, organisasi sektor publik ini telah melakukan diantaranya adalah kegiatan edukatif dan kampanye 'Go Green'. RSAB Soerya bahkan memberikan edukasi secara langsung kepada para pasiennya dan memberi contoh melalui upaya untuk selalu bersih dan sehat dalam layanannya yang tercermin melalui segala sarana dan prasarana yang disediakan bagi para pasiennya.

Hal tersebut juga dilakukan oleh Universitas Widya Kartika melalui kampanye Eco Campus dalam hal budaya bersih, hemat sumber daya, penghijauan, pengelolaan sampah, dan budaya paperless.

\section{Perencanaan Keuangan bagi Pertanggung- jawaban Sosial}

Kegiatan pertanggungjawaban sosial dipandang oleh semua pihak organisasi sektor publik ini dalam dua sisi mata uang, yakni sebagai bentuk kebutuhan dan sebagai bentuk pelengkap. Oleh karena itu oleh beberapa pihak, penganggaran secara khusus sangat jarang ditemui pada organisasi yang melihat kegiatan ini sebagai pelengkap. RSAB Soerya memandang kegiatan terkait dalam hubungan kemasyarakatan sebagai bentuk pencitraan sehingga khusus RSAB Soerya mengandalkan pos-pos lain untuk memenuhi pengeluaran yang timbul tanpa penganggaran yang terpisah atau tersendiri dengan pos khusus.

Hal ini berbeda halnya dengan Universitas Widya Kartika dimana pos anggaran seperti ini biasanya sudah masuk di bagian Humas atau bidang Non Akademik dan sudah direncanakan dalam Rapat Kerja Tahunan.

Lain pula halnya dengan Pondok Pesantren Sunan Drajat yang memandang masyarakat sebagai mitra dimana walaupun perencanaan anggaran sudah ada tetapi kecenderungan untuk meningkat setiap tahunnya akan selalu ada, maka untuk memenuhi kecukupan kebutuhan biasanya dipenuhi tidak hanya mengandalkan sumber daya dari dalam, melainkan juga mengandalkan donasi dari luar organisasi.

\section{Aspek Pemberdayaan dan Pembinaan Karya- wan}

Setiap organisasi sektor publik sudah memperhatikan semua aspek hal-hak karyawan internal dalam standar minimal sesuai undang- undang yang berlaku. RSAB Soerya dan AIDRAT Pondok Pesantren Sunan Drajat sudah melakukan pemberdayaan tenaga kerja dari masyarakat sekitar dan melatihnya dengan ketrampilan kompetensi yang sesuai dengan posisinya.

Sedangkan untuk Universitas Widya Kartika karena terdiri atas tenaga pendidik profesional, maka fokus pembinaan menjadi prioritas untuk tercapainya kualitas pendidik yang selalu update dan refresh dalam setiap perubahan yang terjadi di lingkup pendidikan tinggi maupun keilmuannya.

\section{Aspek Reward dan Punishment}

Pemberian penghargaan dapat berupa pemberian sertifikat, insentif yang menarik ataupun pemberian fasilitas yang memadai. Penghargaan dalam bentuk karyawan teladan, insentif atau bonus di luar dari upah lembur atau Tunjangan hari Raya, pemberian jaminan kesehatan dan jiwa, potongan prosentase pengobatan sampai dengan 20\%, bahkan sampai dengan fasilitasi umroh adalah beberapa contoh reward atas prestasi para karyawan di lingkungan RSAB Soerya.

Pemberian beasiswa pendidikan studi lanjut, bantuan pembiayaan seminar ke luar negeri maupun dalam negeri, pembiayaan kegiatan pelatihan di luar institusi adalah bentuk penghargaan bagi para tenaga pengajar yang mampu memberikan prestasi kewajibannya dalam tridharma di Universitas Widya Kartika.

Sementara di Pondok Pesantren Sunan Drajat, kondisi penghargaan bisa muncul dalam bentuk kombinasi kedua organisasi di atas karena perannya yang sekaligus sebagai lembaga pendukung pendidikan juga dalam organisasi keagamaan. Umroh biasanya diberikan kepada para pengasuh sementara untuk beasiswa biasanya diberikan kepada para santri yang berprestasi.

Dalam hal punishment atau sangsi atas kesalahan yang dilakukan karyawan biasanya dikategorikan berdasarkan tingkat kesalahannya dan dipertimbangkan bentuk hukumannya melalui sistim kode etik organisasi masing-masing. Kejadiannya beraneka dari mulai sangsi yang ringan, skorsing sampai pemutusan hubungan kerja. Hal ini berlaku hampir sama di semua organisasi karena merujuk pada undang-undang ketenagakerjaan.

\section{KESIMPULAN DAN SARAN}

Berdasarkan hasil implementasi Model Audit Pertanggungjawaban Sosial berbasis HCD ditemukan adanya beberapa kondisi atas organisasi sektor publik yang diaudit, diantaranya adalah sebagai berikut: 
a) Dalam preliminary survey yang berfokus pada dokumentasi kelembagaan secara resmi dengan pembagian yang jelas antara hak dan kewajiban pada struktur organisasinya, semua organisasi yang teraudit mampu melewatinya dengan baik. Universitas Widya Kartika dan RSAB Soerya termasuk berkategori baik. Sementara CV. Aidrat termasuk dalam kategori cukup, mengingat skala kelembagaan yang lebih bersifat sektor komersiil walaupun perannya sebagai pendukung dalam sektor publik di Pondok Pesantren Sunan Drajat Lamongan.

b) Dalam hal pengendalian internal di organisasi fungsionalnya dari meliputi aspek pemasaran, akuntansi, keuangan dan personalia, semua organisasi yang teraudit memiliki kinerja yang baik.

c) Dalam hal pertanggungjawaban sosial organisasinya baik secara internal maupun bagi masyarakat, dari meliputi aspek tata nilai organisasi, hubungan masyarakat, lingkungan, pengendalian keuangan dan hubungan dengan karyawan, secara khusus Pondok Pesantren Sunan Drajat memiliki kinerja program yang baik dan menonjol di bidang pola komunikasi dua arah dengan masyarakat, sedangkan RSAB Soerya walaupun masih pola satu arah tetapi memiliki kinerja dan kepercayaan kelembagaan dari masyarakat maupun internal. Berbeda halnya dengan Universitas Widya Kartika yang sedang berbenah untuk meningkatkan kinerja programnya tetapi secara umum masih dalam kategori cukup baik.

Proses penilaian dan pengkategorisasian ini tidak seharusnya meninggalkan faktor nilai deskriptif atas apa yang sudah dilakukan oleh para organisasi ini dalam kegiatan pertanggungjawaban sosialnya. Dengan demikian kuisioner atas tahapan preliminary survey, pengendalian internal maupun kinerja program pertanggungjawaban sosial dapat seharusnya dilengkapi bagian keterangan informasi yang dapat kemudian dikonfirmasi ulang oleh para auditee atau organisasi yang diaudit.

Kegiatan deskriptif ini nantinya dapat bermanfaat dalam merumuskan komponen temuan secara lebih cepat dan dengan teknik afinitif diagram atau pengelompokan berdasarkan tema dapat ditemukan aktifitas-aktifitas apa saja yang menjadi akibat maupun penyebab atas kondisi temuan audit pertanggungjawaban sosial ini.

\section{UCAPAN TERIMA KASIH}

Kami dari tim peneliti menyampaikan terima kasih kepada semua pihak yang telah mendukung proses penelitian sampai penulisan artikel ini, juga kepada pihak Pondok Pesantren Sunan Drajat, RSAB Soerya, Universitas Widya Kartika dan terutama kepada Direktorat Penelitian \& Pengabdian Masyarakat Ditjen Dikti atas kepercayaannya dalam menjadi sponsor penelitian ini melalui Skim PEKERTI untuk tahun anggaran 2014.

\section{DAFTAR PUSTAKA}

Brown, T. (2008). Design Thinking. Harvard Business Review, 84-95.

Brown, T., \& Wyatt, J. (2010). Design Thinking for Social Innovation. Stanford Social Innovation Review, 30-35.

Damayanti, T. W. (2010). Audit Pertanggungjawaban Sosial Perusahaan: Pendekatan Literatur. Jurnal Akuntansi dan Keuangan, 11(2), 101.

Imran, M. (2012). Peran Public Relations Pada Program CSR Dalam Rangka Meningkatkan Citra Positif Perusahaan. Jurnal LPPM: PARADIGMA, 9(01).

Irianta, Yosal. (2004). Community Relations. Konsep dan Aplikasinya. Simbiosa Rekatama Media, Bandung.

Karyana, C. B. (2005). Akuntansi Universitas sebagai Dasar Kepercayaan publik serta jaminan Transparansi dan Akuntabilitas (Kemungkinan Penerapannya di UPNV). EQUITY, 2(1), 81-98.

Munandar, A. (2008). Peran Negara dalam Penguatan Program Pemberdayaan Masyarakat. Jurnal Poelitik , 4(1), 151-161.

Publik, Ikatan Akuntan Indonesia Kompartemen Akuntan (I.A.I.K.A) (2001). Standar Profesional Akuntan Publik. Jakarta: Salemba Empat.

Setioko, Aji. (2010). Pengambilan Keputusan Dalam Perilaku Organisasi. UNNES (Universitas Negeri Semarang).

Suprobo, F. P., Suteja, D., \& Doko S, A. S. (2013). Desain Sistem Informasi Aplikasi Kuisioner Dengan Skala Guttman Atas Pengembangan Model Audit Pertanggungjawaban Sosial Berbasis Human-Centered Design. Prosiding CSGTEIS 2013.

Suwarno, Y. (2009). Inovasi di Sektor Publik. (www.pkailan.com/pdf/inovasi\%20Sektor\%2 OPublik.pdf)<akses 27 Maret 2011>, 1-19.

Zhang, I., Fraser, dan Hill W.Y. (2003) A Comparative Study of Social Audit Models and Reports, Glasgow Caledonian University, UK. 